\title{
HUBUNGAN TINGKAT KELELAHAN SUBJEKTIF DENGAN PRODUKTIVITAS PADA TENAGA KERJA BAGIAN PENGEMASAN DI CV SUMBER BAROKAH
}

\author{
Lince Verawati \\ Ikatan Alumni Kesehatan Masyarakat Indonesia (IAKMI) Provinsi Jawa Timur \\ Email: lincevw@yahoo.com
}

\begin{abstract}
Work fatigue is a subjective feeling followed by declining of efficiency and desire to work. Fatigue can also result in work accident which affect directly to productivity. The purpose of this research was know the relation between subjektive fatigue and labor's productivity at packaging division of chip factory, CV Sumber Barokah. This study was a descriptive study with cross sectional design. Samples were taken with a total sampling principle that all workers from packaging division who totaled 27 people. The variables were years of working life, nutritional status and subjektive fatigue and labor's productivity. The data obtained were analyzed descriptively using Contingency Coeffisient. The results showed that the most of the respondents were 1-2 years of working life, had better nutritional status. The result of fatigue measurement used the checklist which indicated that respondents medium fatigue caused work hours and breaktime is not accordance with provision of labour laws. Respondents can package the chip based on target. The results showed existence between fatigue with labor's productivity. The association values were 0,798 susceptible values from 0.50 to 0.75 which means a moderate level of relationship. The conclusion shows the relation between fatigue with labor's productivity. My suggestion for the corporation is performing work hours and break time in accordance with provision of labour laws number 13 of 2003.
\end{abstract}

Keywords: subjektive fatigue, labor's productivity

\begin{abstract}
ABSTRAK
Kelelahan kerja merupakan suatu perasaan yang bersifat subjektif yang disertai penurunan efisiensi dan kebutuhan dalam bekerja. Kelelahan juga dapat mengakibatkan kecelakaan kerja yang berdampak langsung pada tingkat produktivitas kerjanya. Tujuan penelitian ini mengetahui hubungan antara kelelahan subjektif dengan produktivitas tenaga kerja di pabrik krupuk CV Sumber Barokah bagian pengemasan. Penelitian ini adalah penelitian deskriptif dengan rancangan cross sectional. Sampel diambil dengan prinsip total sampling yaitu semua tenaga kerja bagian pengemasan yang berjumlah 27 orang. Variabel yang diteliti adalah masa kerja, status gizi, kelelahan subjektif dan produktivitas tenaga kerja. Data yang diperoleh kemudian dianalisis secara deskriptif menggunakan koefisien kontingensi. Hasil penelitian menunjukkan bahwa sebagian besar masa kerja responden 1-2 tahun serta memiliki status gizi normal. Hasil pengukuran kelelahan menggunakan checklist menunjukkan bahwa responden yang mengalami kelelahan kerja sedang disebabkan oleh waktu kerja dan waktu istirahat yang tidak sesuai. Responden dengan tingkat kelelahan kerja rendah mampu mengemas krupuk sesuai target sedangkan responden dengan tingkat kelelahan kerja sedang tidak mampu mengemas krupuk sesuai target. Analisis menggunakan koefisien kontingensi didapatkan nilai asosiasi 0,798 berada pada rentang nilai 0,50-0,75 yang berarti memiliki tingkat hubungan sedang. Kesimpulan penelitian ini adalah terdapat hubungan antara kelelahan subjektif dengan produktivitas tenaga kerja. Saran bagi perusahaan yaitu dapat melaksanakan lama waktu kerja dan waktu istirahat sesuai dengan ketentuan perundangan ketenagakerjaan yang berlaku yaitu Undang-Undang Ketenagakerjaan Nomor 13 Tahun 2003.
\end{abstract}

Kata kunci: kelelahan subjektif, produktivitas tenaga kerja

\section{PENDAHULUAN}

Perkembangan teknologi dan industri yang semakin maju akan mendorong munculnya berbagai macam industri yang juga berpengaruh terhadap kompetisi atau persaingan yang semakin ketat di Indonesia. Eksistensi dari masing-masing industri tersebut sangat ditentukan oleh kecepatan, ketepatan dan kualitas produk yang dihasilkan.
Tenaga manusia merupakan salah satu faktor produksi yang berperan di perusahaan mempunyai peran sama dengan faktor produksi lain seperti dana permodalan dan alat produksi. Keberhasilan pembangunan juga sangat bergantung pada manusia sebagai tenaga pelaksananya. Manusia sebagai tenaga kerja mempunyai hak-hak tentang keselamatan kerja yang diatur oleh Undang- 
Undang R.I nomor 1 Tahun 1970 tentang hak atas perlindungan dan jaminan keselamatan kerja untuk kesejahteraan dan peningkatan produktivitas.

Tenaga manusia memerlukan pemeliharaan dan pengembangan khusus karena faktor produksi lainnya tidak akan berarti apa-apa tanpa adanya tenaga manusia, untuk itu perlu adanya upaya kesehatan kerja yaitu melindungi tenaga kerja agar hidup sehat serta terbebas dari gangguan kesehatan dan pengaruh buruk yang diakibatkan yang sesuai dengan Undang-Undang RI No. 39 Tahun 2009 tentang kesehatan.

Salah satu gejala gangguan kesehatan pada tenaga kerja yang timbul akibat pekerjaan adalah kelelahan. Kelelahan kerja merupakan masalah yang sering dijumpai pada tenaga kerja. Kelelahan kerja merupakan masalah penting yang perlu ditanggulangi dengan baik sebab dapat menyebabkan berbagai masalah seperti kehilangan efisiensi dalam bekerja, penurunan produktivitas dan kapasitas kerja serta kemampuan kesehatan dan kemampuan bertahan tubuh yang menyebabkan kecelakaan kerja. Kelelahan juga merupakan penyebab utama terjadinya kecelakaan kerja dan akan berpengaruh terhadap produktivitas.

Penelitian yang dilakukan oleh Setyowati (2014), menyebutkan bahwa kelelahan secara langsung dipengaruhi oleh stres kerja, konflik kerja, lingkungan fisik serta kapasitas kerja. Budiono (2008), mengatakan bahwa kelelahan ditandai dengan melemahnya tenaga kerja dalam melakukan pekerjaan atau kegiatan sehingga akan meningkatkan kesalahan dalam melakukan pekerjaan dan akibat fatalnya yaitu terjadinya kecelakaan kerja.

Data dari International Labour Organitation (2013), menyebutkan sebanyak dua juta pekerja menjadi korban setiap tahun karena kecelakaan kerja akibat faktor kelelahan. Penelitian yang dilakukan International Labour Organitation (2013), menjelaskan bahwa sebanyak 58.118 sampel dari 18.828 sampel $(32,8 \%)$ di antaranya mengalami kelelahan dan berpengaruh pada produktivitas kerja.

Produktivitas di Indonesia sendiri masih relatif rendah jika dibandingkan dengan 3 negara kompetitor lainnya di ASEAN. Data produktivitas tahun 2013 yang dirilis oleh Asian productivity Organization menyebutkan bahwa produktivitas tenaga kerja Indonesia berada di bawah rata-rata negara ASEAN yaitu sebesar 10.700 dollar AS atau 117,7 juta.
Pabrik krupuk CV Sumber Barokah Krian merupakan pabrik krupuk dengan tenaga kerja berisiko mengalami kelelahan kerja. Jam kerja di pabrik krupuk ini yaitu mulai pukul 06.00 WIB sampai 16.00 WIB serta istirahat selama 30 menit pada pukul 12.00-12.30 WIB. Libur tiap 2 minggu sekali pada hari minggu. Berdasarkan UndangUndang Ketenagakerjaan Nomor 13 Tahun 2003 bahwa waktu kerja dan waktu istirahat di pabrik krupuk CV Sumber Barokah tidak sesuai dengan ketetapan yang berlaku.

Waktu kerja yang sesuai Undang-Undang Ketenagakerjaan Nomor 13 Tahun 2003 yaitu untuk 6 hari kerja dalam seminggu waktu kerjanya adalah 7 jam dalam sehari dan 40 jam dalam satu minggu serta untuk 5 hari kerja dalam seminggu waktu kerjanya adalah 8 jam dalam satu hari dan 40 jam dalam satu minggu. Waktu istirahat antara jam kerja yaitu minimal setengah jam setelah bekerja selama 4 jam, kemudian untuk istirahat mingguan yaitu satu hari untuk 6 hari kerja atau 2 hari untuk 5 hari kerja dalam satu minggu.

Tarwaka (2015), mengatakan bahwa jam kerja yang berlebihan dan jam kerja lembur di luar batas kemampuan dapat mempercepat timbulnya kelelahan, menurunkan ketepatan, kecermatan serta ketelitian kerja. Undang-Undang Ketenagakerjaan Nomor 13 Tahun 2003 menjelaskan bahwa pengusaha yang memperkerjakan tenaga kerja melebihi waktu kerja harus memenuhi syarat antara lain ada persetujuan dari tenaga kerja yang bersangkutan serta waktu kerja lembur hanya dapat dilakukan maksimal 3 jam dalam satu hari dan 14 jam dalam 1 minggu. Berdasarkan Undang-Undang Ketenagakerjaan Nomor 13 Tahun 2003 bahwa upah kerja lembur wajib dibayar pengusaha pada tenaga kerja yang bekerja melebihi waktu kerja.

Kelelahan tenaga kerja bagian pengemasan di CV Sumber Barokah juga disebabkan oleh pekerjaan yang bersifat monoton. Keadaan monoton ini berhubungan dengan gerakan-gerakan yang dilakukan pekerja dalam melakukan aktivitas pekerjaannya saat mengemas krupuk yang dilakukan setiap hari secara berulang dan kurang bervariasi.

Anoraga (2009), mengatakan bahwa kelelahan erat kaitannya dengan perasaan bosan akibat pekerjaan yang monoton. Pekerjaan sama yang dilakukan berulang-ulang dari hari ke hari tanpa adanya variasi dapat menimbulkan rasa jemu, bosan dan cepat lelah. Nurmianto (2008), mengatakan bahwa kondisi kerja yang berulang-ulang dapat 
menimbulkan suasana monoton yang berakumulasi menjadi rasa bosan, dimana rasa bosan dikategorikan sebagai kelelahan.

Pabrik krupuk CV Sumber Barokah dalam sehari menargetkan 10 ton krupuk atau 2000 kemasan. Saat kekurangan tenaga kerja karena terdapat tenaga kerja yang tidak masuk, maka krupuk yang dihasilkan dalam sehari hanya mencapai 8-9 ton krupuk yang berarti tidak mencapai target. Sebanyak 10 ton krupuk yang dihasilkan dalam sehari tersebut akan dikemas oleh tenaga kerja pada bagian pengemasan tiap $5 \mathrm{~kg}$ menjadi 2000 kemasan perhari oleh 27 tenaga kerja. Dalam sehari seorang tenaga kerja ditargetkan mengemas sebanyak 74 kemasan. Saat kurang dari jumlah tersebut maka dikatakan produktivitas tenaga kerja bagian pengemasan tidak mencapai target. Berdasarkan wawancara dengan tenaga kerja di bagian pengemasan, penurunan produktivitas disebabkan karena kelelahan sehingga tidak mampu mengemas krupuk sesuai target.

Kelelahan dipengaruhi tiga faktor antara lain faktor lingkungan kerja, faktor pekerjaan dan faktor karakterisitik pekerja. Dalam penelitian ini penulis membatasi faktor penyebab kelelahan yang akan diteliti yaitu masa kerja serta status gizi (IMT). Kedua faktor tersebut menyebabkan terjadinya kelelahan subjektif dan akan mempengaruhi produktivitas tenaga kerja.

Tujuan penelitian ini adalah menganalisis hubungan kelelahan subjektif dengan produktivitas pada tenaga kerja di pabrik krupuk CV Sumber Barokah bagian pengemasan.

\section{METODE}

Penelitian ini merupakan penelitian observasional yaitu dilakukan dengan cara mengamati objek penelitian tanpa memberikan perlakuan. Menurut waktu pelaksanaannya, penelitian ini merupakan penelitian cross sectional karena data tentang variabelnya diperoleh pada satu waktu. Berdasarkan sistem analisisnya, penelitian ini adalah penelitian deskriptif yaitu metode penelitian dengan tujuan membuat gambaran tentang suatu keadaan secara objektif.

Populasi penelitian ini yaitu semua tenaga kerja di pabrik krupuk CV Sumber Barokah bagian pengemasan sebanyak 27 orang. Sampel penelitian ini yaitu tenaga kerja bagian pengemasan di pabrik krupuk CV Sumber Barokah sebanyak 27 orang yang diambil dengan cara teknik total populasi.
Penelitian ini dilaksanakan di pabrik krupuk CV Sumber Barokah dipilih karena belum pernah dijadikan lokasi penelitian sejenis dan berdasarkan hasil survey didapatkan bahwa terdapat tenaga kerja yang mengalami kelelahan kerja karena jam kerja dan jam istirahat yang tidak sesuai sehingga mempengaruhi produktivitas tenaga kerja. Penelitian ini dilakukan pada bulan Oktober 2015.

Variabel pada penelitian ini yaitu masa kerja, status gizi, kelelahan subjektif dan produktivitas tenaga kerja. Sumber data yang digunakan adalah data primer dengan cara wawancara menggunakan kuesioner serta pengukuran secara langsung. Data sekunder digunakan untuk mendukung adanya data primer.

Instrumen dalam penelitian ini adalah kuesioner Subjektif Self Rating Test untuk mengukur kelelahan subjektif, bathroom scale untuk mengukur berat badan dan microtoise untuk mengukur tinggi badan. Kelelahan subjektif diukur menggunakan Subjektive Self Rating Test dari Industrial Fatigue Research Committe (IFRC) Jepang yang berisi 30 pertanyaan yang berisi 10 pertanyaan tentang pelemahan kegiatan, 10 pertanyaan tentang pelemahan motivasi serta 10 pertanyaan tentang gambaran kelelahan fisik.

Data diperoleh dari hasil kuesioner dilakukan scoring untuk mengetahui tingkat kelelahan dan produktivitas tenaga kerja. Data yang didapatkan dari kuesioner dan pengukuran langsung kemudian dianalisis dengan tabel narasi. Data antar variabel dianalisis secara deskriptif menggunakan uji koefisien kontingensi untuk mengetahui kuat hubungan.

\section{HASIL}

\section{Gambaran Umum Perusahaan}

Pabrik krupuk CV Sumber Barokah berlokasi di Krian yang berdiri sejak tahun 2007. Pabrik krupuk ini mempunyai 100 tenaga kerja yang berada pada bagian pengolahan, pencetakan, pengukusan, pengopenan, pengemasan, maintenance dan bengkel serta helper dengan 50 mesin pencetak krupuk, 17 oven basah, 8 mesin oven kering dan mampu memproduksi rata-rata 10 ton kerupuk mentah setiap harinya.

Jam kerja di pabrik krupuk CV Sumber Barokah yaitu mulai pukul 06.00 WIB sampai 16.00 WIB serta istirahat selama 30 menit pada pukul 12.0012.30 WIB. Libur tiap 2 minggu sekali pada hari minggu. 


\section{Karakteristik Responden}

Responden pada penelitian ini adalah tenaga kerja bagian pengemasan di pabrik krupuk CV Sumber Barokah Sidoarjo Jawa Timur sebanyak 27 orang. Penelitian dilakukan pada bulan Oktober 2015.

Tabel 1. Distribusi Masa Kerja Responden

\begin{tabular}{ccc}
\hline Masa Kerja & n & \% \\
\hline $0-2$ th & 17 & 63,0 \\
$2-4$ th & 10 & 37,0 \\
\hline Total & 27 & 100,0 \\
\hline
\end{tabular}

Tabel 1 menunjukkan bahwa responden bekerja dengan masa kerja paling lama yaitu 0-2 tahun (63\%) sedangkan sisanya bekerja dengan masa kerja 2-4 tahun (37\%).

Tabel 2. Distribusi Status Gizi Responden

\begin{tabular}{lrc}
\hline \multicolumn{1}{c}{ IMT } & n & \% \\
\hline Kurus & 2 & 7,4 \\
Normal & 19 & 70,4 \\
Gemuk & 6 & 22,2 \\
\hline \multicolumn{1}{c}{ Total } & $\mathbf{2 7}$ & $\mathbf{1 0 0 , 0}$ \\
\hline
\end{tabular}

Tabel 2 menunjukkan bahwa sebagian besar status gizi responden yaitu dengan status gizi normal $(70,4 \%)$ sedangkan sebagian kecil status gizi responden yaitu dengan status gizi kurus $(7,4 \%)$.

Tabel 3. Distribusi Tingkat Kelelahan Subjektif Responden

\begin{tabular}{lcc}
\hline \multicolumn{1}{c}{ Kategori } & $\mathbf{n}$ & $\mathbf{\%}$ \\
\hline Rendah & 17 & 63,0 \\
Sedang & 10 & 37,0 \\
Tinggi & - & 0,0 \\
Sangat tinggi & - & 0,0 \\
\hline \multicolumn{1}{c}{ Total } & $\mathbf{2 7}$ & $\mathbf{1 0 0 , 0}$ \\
\hline
\end{tabular}

Tabel 3 menunjukkan bahwa sebagian besar responden mengalami tingkat kelelahan rendah $(63 \%)$ sedangkan sisanya responden mengalami tingkat kelelahan sedang (37\%). Tidak ada responden dengan tingkat kelelahan tinggi maupun sangat tinggi.

Tabel 4 menunjukkan bahwa sebagian besar produktivitas responden mampu mengemas krupuk sesuai target $(66,7 \%)$ sedangkan sisanya $(33,3 \%)$ tidak mampu mengemas krupuk sesuai target.
Tabel 4. Distribusi Produktivitas Tenaga Kerja

\begin{tabular}{lcrc}
\hline \multicolumn{1}{c}{ Produktivitas } & Kemasan & n & \% \\
\hline Target & $\geq 74$ & 18 & 66,7 \\
Tidak target & $<74$ & 9 & 33,3 \\
\hline \multicolumn{1}{c}{ Total } & & $\mathbf{2 7}$ & $\mathbf{1 0 0 , 0}$ \\
\hline
\end{tabular}

Tabel 5. Tabulasi Silang Hubungan Masa Kerja dengan Kelelahan Subjektif

\begin{tabular}{rrrr}
\hline \multirow{2}{*}{ Masa } & \multicolumn{2}{c}{ Kategori Kelelahan } & \multirow{2}{*}{ Total } \\
\cline { 2 - 3 } Kerja & \multicolumn{1}{c}{ Rendah } & Sedang & \\
\cline { 2 - 3 } & $\mathbf{n ~ ( \% )}$ & $\mathbf{n}(\mathbf{\%})$ & $\mathbf{n}(\%)$ \\
\hline $1-2$ th & $10(58,8)$ & $7(70,0)$ & $17(63,0)$ \\
$2-4$ th & $7(41,2)$ & $3(30,0)$ & $10(37,0)$ \\
\hline Total & $\mathbf{1 7 ( 1 0 0 , 0 )}$ & $\mathbf{1 0}(\mathbf{1 0 0 , 0 )}$ & $\mathbf{2 7}(\mathbf{1 0 0 , 0 )}$ \\
\hline
\end{tabular}

Tabel 5 menunjukkan bahwa sebagian besar kelelahan rendah dialami oleh responden dengan masa kerja $1-2$ tahun $(58,8 \%)$ sedangkan kelelahan sedang sebagian besar dialami oleh responden dengan masa kerja 1-2 tahun (70\%).

Hasil pengujian dengan menggunakan koefisien kontingensi didapatkan nilai asosiasi 0,111 berada pada rentang nilai $0,00-0,25$ yang berarti memiliki tingkat hubungan lemah. Hal ini menunjukkan bahwa tidak ada hubungan antara masa kerja dengan kelelahan subjektif.

Tabel 6. Tabulasi Silang Hubungan Status Gizi dengan Kelelahan Subjektif

\begin{tabular}{lrrr}
\hline \multirow{2}{*}{$\begin{array}{r}\text { Kate } \\
\text { Gori }\end{array}$} & \multicolumn{2}{c}{ Kategori Kelelahan } & \multirow{2}{*}{ Total } \\
\cline { 2 - 3 } & \multicolumn{1}{c}{ Rendah } & \multicolumn{1}{c}{ Sedang } & \\
\cline { 2 - 3 } $\mathbf{n}(\mathbf{\%})$ & $\mathbf{n}(\mathbf{\%})$ & $\mathbf{n}(\mathbf{\% )})$ \\
\hline Kurus & $1(5,9)$ & $1(10,0)$ & $2(7,4)$ \\
Normal & $12(70,6)$ & $7(70,0)$ & $19(70,4)$ \\
Gemuk & $4(23,5)$ & $2(20,0)$ & $6(22,2)$ \\
\hline Total & $\mathbf{1 7 ( 1 0 0 , 0 )}$ & $\mathbf{1 0 ( 1 0 0 , 0 )}$ & $\mathbf{2 7}(\mathbf{1 0 0 , 0 )}$ \\
\hline
\end{tabular}

Tabel 6 menunjukkan bahwa sebagian besar status gizi responden dengan kelelahan rendah yaitu normal $(70,6 \%)$ sedangkan sebagian kecil dengan status gizi kurus $(5,9 \%)$. Sebagian besar status gizi responden dengan tingkat kelelahan kerja sedang yaitu normal $(70 \%)$ dan sebagian kecil dengan status gizi kurus (10\%).

Hasil pengujian menggunakan koefisien kontingensi didapatkan nilai asosiasi 0,081 berada pada rentang nilai $0.00-0.25$ yang berarti memiliki tingkat hubungan lemah. Hal ini menunjukkan bahwa tidak ada hubungan antara status gizi dengan kelelahan subjektif. 
Tabel 7. Tabulasi Silang Hubungan Kelelahan Subjektif dengan Produktivitas

\begin{tabular}{lccc}
\hline \multirow{2}{*}{ Produktivitas } & \multicolumn{2}{c}{ Kategori Kelelahan } & \multirow{2}{*}{ Total } \\
\cline { 2 - 3 } & Rendah & Sedang & \\
\cline { 2 - 3 } & $\mathbf{n ~ ( \% )}$ & $\mathbf{n ~ ( \% )}$ & $\mathbf{n}(\%)$ \\
\hline Target & $14(82,4)$ & $4(40)$ & $18(66,7)$ \\
Tidak & $3(17,6)$ & $6(60)$ & $9(33,3)$ \\
Target & & & \\
\hline \multicolumn{1}{c}{ Total } & $\mathbf{1 7 ( 1 0 0 )}$ & $\mathbf{1 0 ( 1 0 0 )}$ & $\mathbf{2 7 ( 1 0 0 )}$ \\
\hline
\end{tabular}

Hasil penelitian menunjukkan bahwa sebagian besar responden dengan kelelahan kerja rendah mampu mengemas krupuk sesuai target $(82,4 \%)$ sedangkan sebagian responden dengan tingkat kelelahan kerja sedang tidak mampu mengemas krupuk sesuai target (60\%).

Hasil pengujian dengan menggunakan kontingensi koefisien didapatkan nilai asosiasinya sebesar 0,798 berada pada rentang nilai $0,50-0,75$ yang berarti memiliki tingkat hubungan sedang. Hal ini menunjukkan bahwa terdapat hubungan antara kelelahan kerja dengan produktivitas tenaga kerja.

\section{PEMBAHASAN}

\section{Masa Kerja}

Hasil penelitian menunjukkan bahwa responden bekerja dengan masa kerja paling lama yaitu 0-2 tahun $(63 \%)$. Hal ini menunjukkan tenaga kerja yang bekerja di pabrik krupuk CV Sumber Barokah merupakan tenaga kerja baru dengan masa kerja tidak lebih dari 2 tahun. Tenaga kerja di pabrik krupuk CV Sumber Barokah tersebut banyak yang keluar masuk dikarenakan jam kerja dan jam istirahat yang tidak sesuai sehingga banyak yang mengeluhkan kelelahan dan memilih untuk resign dari pekerjaan tersebut.

Masa kerja responden di pabrik krupuk CV sumber barokah sebagian kecil yaitu 2-4 tahun. Hal ini menunjukkan bahwa tidak banyak tenaga kerja yang bekerja dengan waktu lebih dari 2 tahun.

Sedarmayanti (2011), menyatakan bahwa pekerjaan fisik yang dilakukan secara terus-menerus akan mempengaruhi mekanisme dalam tubuh seperti sistem pencernaan otot, peredaran darah, syaraf serta pernafasan. Dalam keadaan ini produk sisa dalam otot dan peredaran darah akan terkumpul dan membatasi kelangsungan otot sehingga menyebabkan kelelahan.

Masa kerja seseorang berpengaruh terhadap pekerjaan seseorang. Semakin lama seseorang bekerja seseorang akan lebih berpengalaman dalam melakukan pekerjaannya dan mampu beradaptasi dengan pekerjaan serta lingkungannya. Suma'mur (2009), mengatakan bahwa tenaga kerja akan beradaptasi dengan pekerjaan dan lingkungan kerjanya. Meningkatnya keterampilan kerja akan membuat tubuh manusia semakin efisiensi dalam melakukan pekerjaannya sehingga beban kerja akan berkurang dan timbulnya kelelahan akan berkurang.

Efek negatif yang ditimbulkan dari seseorang dengan masa kerja yang lama yaitu batas ketahanan tubuh yang berlebihan karena tekanan yang didapatkan pada proses kerja yang akan menimbulkan kelelahan. Tekanan fisik akan terakumulasi setiap hari pada suatu masa yang panjang mengakibatkan berkurangnya kinerja otot dan menyebabkan makin rendahnya gerakan.

\section{Status Gizi}

Hasil penelitian menunjukkan bahwa sebagian besar status gizi responden yaitu dengan IMT normal $(70,4 \%)$. Status gizi mempengaruhi kelelahan. Tenaga kerja dengan status gizi baik mempunyai mekanisme pemulihan dari kelelahan kerja yang lebih baik. Hal ini akan mengurangi efek kumulatif dari kelelahan sehingga kelelahan yang terjadi akan semakin rendah. Status gizi yang baik berpengaruh positif terhadap daya kerja pekerja sedangkan apabila asupan kalori pekerja tidak sesuai dengan kebutuhan maka pekerja akan lebih cepat mengalami kelelahan.

Hasil penelitian menunjukkan bahwa terdapat responden dengan status gizi gemuk $(22,2 \%)$. Suhardjo (2007), mengatakan bahwa tubuh akan cepat menjadi lelah apabila mengonsumsi zat makanan secara berlebih yang disebabkan oleh kelebihan energi oleh tubuh sehingga menimbun asam laktat. Budiono (2008), mengatakan bahwa beban yang berlebihan kadang-kadang meningkatkan selera makan yang menjadikan sebagai salah satu penyebab bertambahnya berat badan dan kegemukan.

Almatsier (2006), mengatakan bahwa status gizi lebih terjadi karena tubuh memperoleh zat-zat gizi dalam jumlah berlebihan, sehingga menimbulkan efek toksik yang membahayakan. Hal ini dapat mengakibatkan terjadinya gangguan gizi yang dapat menyebabkan daya kerja tenaga kerja yang kurang optimal bahkan kinerja menjadi menurun.

Hasil penelitian juga menunjukkan bahwa sebagian kecil status gizi responden yaitu kurus 
(7,4\%). Suma'mur (2009), mengatakan bahwa status gizi kurang cenderung untuk mengalami kelelahan karena adanya keterbatasan atau ketidakseimbangan cadangan gizi yang akan dirubah menjadi energi saat beraktivitas.

Teori mengenai zat gizi esensial menjelaskan bahwa fungsi gizi terbagi menjadi tiga yaitu sebagai sumber energi, zat pengatur serta zat pembangun. Tenaga kerja membutuhkan energi untuk dapat bekerja. Pemenuhan gizi ini tidak hanya harus dipenuhi secara kuantitatif, namun juga secara kualitas gizi dari makanan yang dikonsumsi. Makan yang cukup dan seimbang pada siang hari dan sebelum tidur secara signifikan mempengaruhi kewaspadaan dan kualitas tidur. Menjaga kesehatan dan kondisi berat badan dapat meningkatkan stamina dan juga dapat mengurangi kemungkinan gangguan tidur. Gizi yang tepat serta kondisi fisik yang baik mampu berpengaruh penting efek kelelahan.

\section{Tingkat Kelelahan Kerja}

Kelelahan kerja diukur menggunakan Subjektive Self Rating Test dari Industrial Fatigue Research Committe (IFRC) Jepang. Kuesioner tersebut berisi 30 pertanyaan pelemahan kegiatan, pelemahan motivasi dan gambaran kelelahan fisik. Sepuluh pertanyaan mengenai pelemahan kegiatan yaitu menanyakan apakah responden pernah mengalami perasaan berat di kepala, beban pada mata, mengantuk, pikiran kacau, lelah di seluruh badan, berat di kaki, menguap, gerakan canggung dan kaku, berdiri tidak stabil dan ingin berbaring.

Sepuluh pertanyaan tentang pelemahan motivasi menanyakan apakah responden pernah mengalami susah berpikir, tidak berkonsentrasi, lelah untuk bicara, gugup, sulit untuk memusatkan perhatian, mudah lupa, kepercayaan diri berkurang, sulit mengontrol sikap, merasa cemas tidak tekun dalam pekerjaan. Sepuluh pertanyaan tentang gambaran kelelahan fisik yaitu berupa pertanyaan mengenai sakit kepala di kepala, spasme di kelopak mata, sesak nafas, kaku di bahu, nyeri di punggung, haus, suara serak, merasa pening, tremor pada anggota badan dan merasa kurang sehat.

Tiga puluh pertanyaan mengenai kelelahan kerja subjektif dilakukan skoring menggunakan 4 skala likert. Penilaian kelelahan subjektif dengan 4 skala likert dimana pemberian skor 0 apabila tidak pernah merasakan keluhan, skor 1 apabila kadang-kadang merasakan keluhan, skor 2 apabila sering merasakan keluhan dan skor 3 apabila sering sekali merasakan keluhan. Total skor yang diperoleh kemudian dijumlah dan dikategorikan menjadi tingkat kelelahan kerja yaitu skor 0-21 adalah kategori kelelahan rendah, skor 22-44 adalah kategori kelelahan sedang, skor 45-67 kategori kelelahan tinggi dan skor 68-90 adalah kategori kelelahan sangat tinggi.

Hasil penelitian menunjukkan bahwa sebagian besar responden mengalami tingkat kelelahan kerja rendah $(63 \%)$. Sisanya responden mengalami tingkat kelelahan kerja sedang (37\%). Kelelahan kerja pada tenaga kerja di pabrik krupuk CV Sumber Barokah disebabkan oleh waktu kerja dan waktu istirahat yang tidak sesuai. Waktu kerja di pabrik krupuk ini yaitu mulai pukul 06.00-16.00 WIB. Sedangkan waktu istirahat yaitu pukul 12.00-12.30 WIB. Libur tiap 2 minggu sekali pada hari minggu.

Waktu kerja yang sesuai dengan UndangUndang Ketenagakerjaan No. 13 Tahun 2003 Pasal 7 ayat 2 yaitu untuk 6 hari kerja waktu kerja yang sesuai yaitu 7 jam dalam sehari dan 40 jam dalam seminggu. Waktu kerja untuk 5 hari kerja yaitu 8 jam dalam sehari dan 40 jam dalam seminggu. Pengusaha juga wajib memberi waktu istirahat dan waktu cuti untuk tenaga kerja.

Waktu istirahat antara jam kerja yaitu minimal setengah jam setelah bekerja 4 jam bekerja, kemudian untuk istirahat mingguan yaitu satu hari untuk 6 hari kerja dalam satu minggu atau 2 hari untuk 5 hari kerja dalam satu minggu. Tarwaka (2015), mengatakan bahwa jam kerja yang berlebihan dan jam kerja lembur di luar batas kemampuan dapat mempercepat timbulnya kelelahan, menurunkan ketepatan, kecermatan dan ketelitian kerja.

Pengusaha yang mempekerjakan tenaga kerja melebihi waktu kerja harus memenuhi syarat sesuai dengan yang ada di Undang-Undang Ketenagakerjaan Nomor 13 Tahun 2003 yaitu ada persetujuan tenaga kerja yang bersangkutan serta waktu kerja lembur hanya dapat dilakukan maksimal 3 jam sehari dan 14 jam seminggu.

Upah lembur wajib diberikan kepada tenaga kerja yang bekerja melebihi waktu kerja sesuai dengan Undang-Undang Ketenagakerjaan Nomor 13 Tahun 2003. Syarat mengenai kerja lembur diatur oleh Keputusan Menteri Tenaga Kerja dan Transmigrasi RI. Kep. 102/MEN/VI/2004. Berdasarkan peraturan tersebut, bagi pengusaha yang mempekerjakan tenaga kerja selama waktu lembur wajib untuk membayar upah kerja lembur, memberi kesempatan untuk istirahat secukupnya dan memberikan makanan dan minuman minimal sebanyak 1.400 kalori apabila melaksanakan kerja 
lembur selama 3 jam atau lebih (tidak boleh diganti dengan uang).

Kelelahan tenaga kerja bagian pengemasan di CV Sumber Barokah juga disebabkan oleh keadaan monoton yang dilakukan oleh tenaga kerja bagian pengemasan. Hasil penelitian ini sejalan dengan penelitian yang dilakukan Perwitasari (2014), bahwa pekerjaan monoton yang dilakukan secara berulangulang menyebabkan kelelahan.

Keadaan monoton berhubungan dengan gerakan-gerakan yang dilakukan pekerja dalam melakukan aktivitas pekerjaannya saat mengemas krupuk yang dilakukan setiap hari secara berulang dan kurang bervariasi. Anoraga (2009), mengatakan bahwa kelelahan erat kaitannya dengan perasaan bosan akibat pekerjaan yang monoton. Pekerjaan sama yang dilakukan berulang-ulang dari hari ke hari tanpa adanya variasi dapat menimbulkan rasa jemu, bosan dan cepat lelah. Nurmianto (2008), kondisi kerja yang berulang-ulang dapat menimbulkan suasana monoton yang berakumulasi menjadi rasa bosan, di mana rasa bosan dikategorikan sebagai kelelahan.

Beban kerja juga merupakan faktor penyebab terjadinya kelelahan. Beban kerja dapat berupa fisik, mental atau sosial. Suma'mur (2009), mengatakan bahwa beban kerja yang besar akan lebih besar pula terjadi kelelahan.

Kelelahan kerja yang dialami oleh tenaga kerja bagian pengemasan di pabrik krupuk CV Sumber Barokah ini bisa juga disebabkan oleh faktor psikologis. Faktor psikologis ini ditandai dengan pekerja merasa lelah meskipun mereka tidak mengerjakan apa pun, hal ini disebabkan oleh adanya konflik mental yang dikarenakan oleh pekerjaannya sendiri, teman sekerjanya, atasannya ataupun kejadian di rumah tangga atau dalam pergaulan hidupnya di masyarakat (Suma'mur, 2009).

Gilmer dan Cameron dalam Setyawati (2010), mengatakan bahwa gejala kelelahan yang dialami oleh tenaga kerja bisa bermacam-macam mulai dari penurunan kesiagaan dan perhatian, cara berpikir atau perbuatan anti sosial, penurunan dan hambatan persepsi, depresi, tidak cocok dengan lingkungan, kurang tenaga dan kehilangan inisiatif. Sedangkan gejala lainnya dapat berupa sakit kepala, vertigo, kehilangan nafsu makan, gangguan paru dan jantung serta gangguan kecemasan dan perubahan tingkah laku.

Kelelahan dapat diatasi dengan berbagai macam cara sesuai dengan penyebabnya. Tarwaka (2015), mengatakan bahwa salah satu cara mengatasi kelelahan yaitu dengan cara bagaimana setiap kelelahan yang muncul tidak menjadi kronis. Beberapa cara mengatasi kelelahan kerja yang terjadi pada tenaga kerja di pabrik krupuk CV Sumber Barokah yaitu dengan cara sesuai kapasitas kerja fisik dan mental, kerja lebih bervariasi dan dinamis, kebutuhan kalori seimbang serta istirahat cukup setiap 2 jam kerja dengan sedikit kudapan.

\section{Produktivitas Tenaga Kerja}

Hasil penelitian menunjukkan bahwa sebagian besar responden mampu mengemas krupuk sesuai target $(66,7 \%)$ sedangkan sisanya mengemas krupuk tidak sesuai target $(33,3 \%)$.

Produktivitas kerja yang tidak sesuai target bisa dikarenakan oleh kelelahan kerja pada tenaga kerja yang dapat mempengaruhi produktivitas kerja itu sendiri. Kelelahan fisik dan mental merupakan faktor penyebab terjadinya kondisi kelelahan yang berakibat terhadap turunnya produktivitas tenaga kerja dalam melakukan tugasnya. Hasibuan (2010) mengatakan bahwa semakin tinggi tingkat kelelahan kerja fisik dan mental seseorang maka produktivitas dapat menurun

\section{Hubungan antar Variabel}

\section{Hubungan Masa Kerja dengan Kelelahan Subjektif}

Hasil penelitian menunjukkan bahwa sebagian besar kelelahan kerja sedang dialami oleh responden dengan masa kerja 1-2 tahun. Sedangkan kelelahan kerja sedang sebagian kecil dialami oleh responden dengan masa kerja 2-4 tahun. Hasil penelitian ini menunjukkan bahwa semakin lama masa kerja seseorang maka dia tidak mudah lelah.

Uji statistik antara masa kerja dengan kelelahan dengan menggunakan kontingensi koefisien didapatkan nilai asosiasinya sebesar 0,111 berada pada rentang nilai $0.00-0.25$ yang berarti memiliki tingkat hubungan lemah. Hasil ini menunjukkan bahwa tidak ada hubungan antara masa kerja dengan kelelahan kerja di pabrik krupuk CV Sumber Barokah bagian pengemasan. Tidak adanya hubungan ini menunjukkan bahwa faktor masa kerja bukan merupakan faktor yang berhubungan secara langsung dengan terjadinya kelelahan kerja.

Hasil penelitian hubungan masa kerja dengan kelelahan ini bertentangan dengan penelitian yang dilakukan oleh Muizzudin (2013), yang menyebutkan bahwa masa kerja berpengaruh terhadap kelelahan kerja. Tenaga kerja dengan masa 
kerja lebih dari 5 tahun banyak yang mengalami kelelahan dibanding dengan tenaga kerja dengan masa kerja kurang dari 1 tahun. Hal ini dikarenakan pekerjaan monoton menyebabkan pembebanan otot secara statis yang menyebabkan nyeri otot tulang, tendon, dan sebagainya. Kelelahan kerja juga disebabkan rasa bosan yang dialami tenaga kerja sehingga sebelum memulai pekerjaan, tenaga kerja sudah merasakan lelah.

Notoatmodjo (2010), mengatakan bahwa masa kerja seseorang cenderung akan membuat orang merasa betah dan beradaptasi dengan lingkungannya yang baru. Selain itu, masa kerja hanya menggambarkan lama kerja seseorang.

Masa kerja seseorang berpengaruh terhadap pekerjaan seseorang. Semakin lama seseorang bekerja seseorang akan lebih berpengalaman dalam melakukan pekerjaannya, namun masa kerja juga akan berpengaruh negatif apabila seorang pekerja mengalami kelelahan dan kebosanan.

Sedarmayanti (2011), menyatakan bahwa pekerjaan fisik yang dilakukan secara berkelanjutan dalam jangka waktu yang panjang akan mempengaruhi mekanisme dalam tubuh seperti sistem peredaran darah, pencernaan otot, syaraf dan pernafasan. Dalam keadaan ini produk sisa dalam otot dan peredaran darah akan terkumpul dan membatasi kelangsungan otot sehingga menyebabkan kelelahan.

Masa kerja seseorang berpengaruh terhadap pekerjaan seseorang. Semakin lama seseorang bekerja seseorang akan lebih berpengalaman dalam melakukan pekerjaannya dan mampu beradaptasi dengan pekerjaan serta lingkungannya. Tenaga kerja dapat menurunkan ketegangan dan peningkatan performansi kerja.

Suma'mur (2009), mengatakan bahwa tenaga kerja akan beradaptasi dengan pekerjaan dan lingkungan kerjanya. Meningkatnya keterampilan kerja akan membuat tubuh manusia semakin efisiensi dalam melakukan pekerjaannya sehingga beban kerja akan berkurang dan timbulnya kelelahan akan berkurang sedangkan efek negatif yang ditimbulkan yaitu batas ketahanan tubuh yang berlebihan karena tekanan yang didapatkan pada proses kerja yang akan menimbulkan kelelahan. Tekanan fisik akan terakumulasi setiap hari pada suatu masa yang panjang mengakibatkan berkurangnya kinerja otot dan menyebabkan makin rendahnya gerakan.

\section{Hubungan Status Gizi dengan Kelelahan Subjektif}

Hasil penelitian menunjukkan bahwa sebagian besar status gizi responden dengan kelelahan kerja sedang yaitu normal $(70 \%)$ dan terdapat pula responden dengan status gizi gemuk $(20 \%)$ dan status gizi kurus $(10 \%)$. Hal ini menunjukkan bahwa tenaga kerja di pabrik krupuk CV Sumber Barokah memiliki status gizi baik yang berarti kondisi tubuh normal dan memungkinkan tenaga kerja terhindar dari kelelahan. Semakin baik asupan gizi seseorang maka tingkat kelelahan kerja seseorang akan berkurang.

Penelitian yang dilakukan (Atiqoh, 2014) menyebutkan bahwa kelelahan kerja berat diderita oleh responden dengan status gizi normal. Hasil ini menunjukkan bahwa terdapat faktor lain yang berpengaruh terhadap kelelahan misalnya umur dan masa kerja.

Uji statistik hubungan antara gizi dengan kelelahan kerja menggunakan kontingensi koefisien didapatkan nilai asosiasinya sebesar 0,081 berada pada rentang nilai $0.00-0.25$ yang berarti memiliki tingkat hubungan lemah. Hal ini menunjukkan bahwa tidak ada hubungan antara status gizi dengan kelelahan tenaga kerja di pabrik krupuk CV Sumber Barokah bagian pengemasan.

Status gizi mempengaruhi kelelahan. Tenaga kerja dengan status gizi baik mempunyai mekanisme pemulihan dari kelelahan kerja yang lebih baik. Hal ini akan mengurangi efek kumulatif dari kelelahan sehingga kelelahan yang terjadi akan semakin rendah. Status gizi yang baik berpengaruh positif terhadap daya kerja pekerja. Sedangkan, apabila asupan kalori pekerja tidak sesuai dengan kebutuhan maka pekerja akan lebih cepat mengalami kelelahan.

Hasil penelitian menunjukkan bahwa terdapat responden dengan status gizi gemuk $(22,2 \%)$. Hal ini memungkinkan bahwa asupan gizi mereka terlalu berlebih dan tidak seimbang sehingga menimbulkan kelebihan berat badan. Beban yang cukup tinggi kadang membuat selera makan seseorang bertambah sehingga berakibat pada kenaikan berat badan.

Almetsier (2006), mengatakan bahwa status gizi lebih disebabkan oleh tubuh memperoleh zat-zat gizi yang berlebih sehingga menimbulkan efek toksik yang berbahaya dan berakibat pada gangguan gizi yang menyebabkan kinerja seseorang menurun dan 
daya kerja yang kurang optimal. Status gizi lebih apabila dikaitkan dengan kelelahan maka menurut Suhardjo (2007), bahwa tubuh akan cepat menjadi lelah apabila mengonsumsi zat makanan secara berlebih yang disebabkan oleh kelebihan energi oleh tubuh sehingga menimbun asam laktat.

Budiono (2008), mengatakan bahwa beban yang berlebihan kadang-kadang meningkatkan selera makan yang menjadikan sebagai salah satu penyebab bertambahnya berat badan dan kegemukan. Menurut Almatsier (2006), status gizi lebih terjadi karena tubuh memperoleh zat-zat gizi dalam jumlah berlebihan, sehingga menimbulkan efek toksik yang membahayakan. Hal ini dapat mengakibatkan terjadinya gangguan gizi yang dapat menyebabkan daya kerja tenaga kerja yang kurang optimal bahkan kinerja menjadi menurun.

Hasil penelitian juga menunjukkan bahwa sebagian kecil status gizi responden yaitu kurus (7,4\%). Suma'mur (2009), mengatakan bahwa status gizi kurang cenderung untuk mengalami kelelahan karena adanya keterbatasan atau ketidakseimbangan cadangan gizi yang akan dirubah menjadi energi saat beraktivitas.

Menurut teori mengenai zat gizi esensial bahwa fungsi gizi terbagi menjadi tiga yaitu sebagai sumber energi, zat pengatur serta zat pembangun. Tenaga kerja membutuhkan energi untuk dapat bekerja. Pemenuhan gizi ini tidak hanya harus dipenuhi secara kuantitatif, namun juga secara kualitas gizi dari makanan yang dikonsumsi. Makan yang cukup dan seimbang pada siang hari dan sebelum tidur secara signifikan mempengaruhi kewaspadaan dan kualitas tidur. Menjaga kesehatan dan kondisi berat badan dapat meningkatkan stamina dan juga dapat mengurangi kemungkinan gangguan tidur. Gizi yang tepat serta kondisi fisik yang baik mampu berpengaruh penting efek kelelahan.

\section{Hubungan Tingkat Kelelahan Subjektif dengan Produktivitas Tenaga Kerja}

Hasil penelitian menunjukkan bahwa mayoritas responden dengan kelelahan kerja rendah mampu mengemas krupuk sesuai target $(77,8 \%)$. Sebagian besar responden dengan tingkat kelelahan kerja sedang tidak mampu mengemas krupuk sesuai target $(66,7 \%)$.

Berdasarkan uji statistik hubungan antara kelelahan dengan produktivitas tenaga kerja dengan menggunakan kontingensi koefisien didapatkan nilai asosiasinya sebesar 0,398 berada pada rentang nilai 0,26-0,50 yang berarti memiliki tingkat hubungan sedang. Hal ini menunjukkan bahwa ada hubungan antara kelelahan kerja dengan produktivitas tenaga kerja di pabrik krupuk CV Sumber Barokah bagian pengemasan.

Hasil penelitian hubungan kelelahan dengan produktivitas sejalan dengan penelitian yang dilakukan Ulfah (2013), pada tenaga kerja di penggilingan padi menyebutkan bahwa kelelahan kerja berhubungan dengan produktivitas. Produktivitas meningkat seiring dengan berkurangnya tingkat kelelahan di penggilingan padi. Produktivitas meningkat 1 ton/hari ketika terjadi kenaikan 1 mili/detik kelelahan kerja.

Produktivitas kerja yang tidak sesuai target bisa dikarenakan oleh kelelahan kerja pada tenaga kerja yang dapat mempengaruhi produktivitas kerja itu sendiri. Kelelahan fisik dan mental merupakan faktor penyebab terjadinya kondisi kelelahan yang berakibat terhadap turunnya produktivitas tenaga kerja dalam melakukan tugasnya. Hasibuan (2010), mengatakan bahwa semakin tinggi tingkat kelelahan kerja fisik dan mental seseorang maka produktivitas dapat menurun

Budiono (2008), mengatakan bahwa terdapat hubungan antara kelelahan dan produktivitas terutama di suatu perusahaan. Hal ini berarti jika seorang tenaga kerja mengalami kelelahan fisik maupun psikis maka akan memberikan dampak pada produktivitas tenaga kerja khususnya menurunnya produktivitas perusahaan.

Dampak dari kelelahan kerja bisa dicegah dengan berbagai macam cara di antaranya mengurangi penyebab timbulnya kelelahan. Tenaga kerja dapat melakukan peregangan otot misalnya menggerakkan kepala, tangan, dan kakinya diselasela pekerjaannya ataupun saat istirahat, agar tubuh tidak terlalu lama dalam keadaan statis yang terjadi berulang kali. Perusahaan hendaknya juga menerapkan waktu kerja dan waktu istirahat yang sesuai agar tenaga kerja tidak mudah mengalami kelelahan sesuai dengan yang tertera pada UndangUndang Ketenagakerjaan Nomor 13 Tahun 2013 tentang waktu kerja dan waktu istirahat.

\section{SIMPULAN}

Responden sebagian besar berumur lebih dari 30 tahun, sebagian besar responden bekerja dengan masa kerja 0-2 tahun, sebagian besar responden memiliki status gizi normal.

Tidak ada hubungan masa kerja dengan kelelahan subjektif, tidak ada hubungan status gizi 
dengan kelelahan subjektif, terdapat hubungan kelelahan subjektif dengan produktivitas.

Perusahaan diharapkan untuk dapat melaksanakan lama waktu kerja dan waktu istirahat sesuai dengan ketentuan perundangan ketenagakerjaan yang berlaku yaitu Undang-Undang Ketenagakerjaan No. 13 Tahun 2003 tentang waktu kerja dan waktu istirahat serta Kepmenakertrans R.I Kep. 102/MEN/VI/2004.

\section{DAFTAR PUSTAKA}

Almatsier, S. 2006. Prinsip Dasar Ilmu Gizi, edisi ke-6. Jakarta: Gramedia Pustaka Utama.

Atiqoh, J. 2014. Faktor-faktor yang berhubungan dengan Kelelahan Kerja pada Pekerja Konveksi Bagian Penjahitan di CV Aneka Garment Gunungpati Semarang. Jurnal Kesehatan Masyarakat (e-Journal), Volume 2, Nomor 2, Februari 2014.

Anoraga, P. 2009. Psikologi Kerja. Jakarta: Rieneka Cipta.

Budiono, A. 2008. Bunga Rampai Higiene Perusahaan (Hiperkes) dan Kesehatan dan Keselamatan Kerja. Semarang: BP Universitas Diponegoro.

Depnaker dan Transmigrasi R.I. 2003. UndangUndang Ketenagakerjaan R.I. No. 13 Tahun 2003. Jakarta.

Keputusan Menteri Tenaga Kerja dan Transmigrasi Republik Indonesia Nomor Kep. 102/MEN/ VI/2004 tentang Waktu Kerja Lembur dan Upah Kerja Lembur.

ILO. 2013. The Prevention of Occupational Diseases. Geneva: International Labour Organization.

Muizzudin, A. 2013. Hubungan Kelelahan dengan Produktivitas Kerja pada Pekerja Tenun di PT. Alkatex Tegal. Unnes Journal of Public Health UJPH 2 (4) 2013.

Notoatmodjo, S. 2010. Kesehatan Masyarakat: Ilmu dan Seni. Jakarta: Rineka Cipta.
Nurmianto, E. 2008. Ergonomi konsep dasar dan aplikasi. Surabaya: PT. Guna Widya.

Perwitasari, D. 2014. Faktor yang Berhubungan dengan Kelelahan Kerja Subjektif pada Perawat di Rsud Dr. Mohamad Soewandhie Surabaya. The Indonesian Journal of Safety, Health and Environment. Volume 1 No. 1, Januari-April 2014.

Sedarmayanti. 2011. Tata Kerja dan Produktivitas Kerja. Cetakan Ketiga. Bandung: Mandar Maju.

Setyawati. 2010. Selintas tentang Kelelahan Kerja. Yogyakarta: Amara Books.

Setyowati, L. 2014. Penyebab Kelelahan Kerja pada Pekerja Mebel. Jurnal Kesehatan Masyarakat Nasional Vol. 8 No. 8 Mei 2014.

Suhardjo. 2007. Perencanaan Pangan dan Gizi. Jakarta: Bumi Aksara.

Suma'mur, P.K. 2009. Hygiene Perusahaan dan Kesehatan Kerja. Jakarta: Gunung Agung.

Tarwaka. 2014. Ergonomi Industri. Dasar-Dasar Pengetahuan Ergonomi dan Aplikasi di Tempat Tugas. Surakarta: Harapan Press.

Ulfah, N. 2013. Model Kuantitatif Manajemen Kelelahan dan Beban Kerja untuk peningkatan Produktivitas Pekerja Penggilingan Padi. Jurnal Kesehatan Masyarakat Nasional Vol. 7, No. 10, Mei 2013.

Undang-Undang Republik Indonesia Nomor 1 Tahun 1970 tentang Keselamatan Kerja.

Undang-Undang Republik Indonesia No 39 Tahun 2009 Tentang Kesehatan.

Verawati, L. 2016. Gambaran Kelelahan Kerja Subjektif dan Produktivitas (Studi pada Tenaga Kerja Bagian Pengemasan di Pabrik Krupuk CV Sumber Barokah. Skripsi. Surabaya: Universitas Airlangga. 